\title{
Polyphenolic compounds transition into protein-plant concentrates during the deposition of milk proteins by Plantago major $L$.
}

\section{Olena Grek ${ }^{1}$, Larisa Chubenko' ${ }^{1}$, Amit Kumar ${ }^{2}$, Volodymyr Khareba ${ }^{3}$, Alla Tymchuk ${ }^{1}$, Olena Onopriichuk ${ }^{1}$}

\author{
1 - National University of Food Technologies, Kyiv, Ukraine \\ 2 - Integral University, Lucknow, India \\ 3 - Department of Agricultural Economics and Food of the National Academy of Agrarian \\ Sciences of Ukraine
}

Keywords:

Milk

Plantago major L.

Coagulation

Protein

Polyphenolic

Article history:

Received

24.05.2019

Received in revised

form 29.09.2019

Accepted

28.11.2019

Corresponding

author:

Olena Onopriichuk

E-mail:

olena.onopriychuk@

gmail.com

DOI:

$10.24263 / 2304-$

974X-2019-8-4-6

\section{Abstract}

Introduction. Implementation of scientifically sound use principles of dairy and plant raw materials with functionaltechnological properties is relevant.

Materials and methods. Normalized milk was used as the raw material to obtain protein concentrates. As a coagulant in the deposition of proteins used juice of direct extraction from the terrestrial part of Plantago major L. Identification and quantification of polyphenols and flavanoids in the samples of the plantain juice and the obtained whey was performed by high-performance liquid chromatography using system Prominence LC-20 Shimadzu (Japan). Comparisons were made with external standard samples.

Results and discussion. The study of the qualitative composition and quantitative content of polyphenols and flavonoids in protein-plant concentrates obtained by deposition of milk proteins with the juice of direct extraction of the terrestrial part of Plantago major L were presented. The process took place at elevated temperatures. According to the analysis of absorption spectra of the experimental samples of juice from the plantain found that the maximum is at wavelengths of $225-350 \mathrm{~nm}$. This result is correlated with the fact that of the 22 isolated flavonoids, 9 substances are 6oxyflavones, characterized by a maximum within the range of 255$285 \mathrm{~nm}$.

The difference between the content of polyphenols in Plantago major $L$. juice and whey indicates the degree of transition of polyphenolic compounds into protein-plant concentrates. The total content of flavonoids in all tested samples was equal to the content of substances that were similar to the standards of flavonoids (phenolic acids, catechins, flavonols, flavonones and flavones) with the exception of catechin-like substances. Flavonols are represented by the glycosides of myricetin. Naringin and hesperidin are part of flavonones. The flavones in the quantitative sense are of the lowest weight and are represented by luteolin and its glycosides and glycosides of apigenin. Phenolic acids content ranged from 12.36 $\mathrm{mg} / \mathrm{l}$ for plantain juice and $0.07 \mathrm{mg} / \mathrm{l}$ for colored whey.

Conclusions. The degree of polyphenolic compounds transition in protein-plant concentrate was determined at the level $77 \%$ of the total amount, of which $74 \%$ are flavonoids. 


\section{Introduction}

The actual direction is the implementation of the scientifically sound use principles of dairy and plant raw materials with functional-technological properties. Such modifications, under the conditions of the traditional technological process, are able to give the products new qualities other than simple mixing of raw materials [1].

It is advisable to determine the technological action of plant raw materials with biologically active substances in dairy products. First of all, it concerns the process of milk proteins deposition using wild plant, namely Plantago major $L$. This plant is widely distributed worldwide, used as a medicinal raw material, and has a positive effect on health $[2,3]$. In addition, the plantain is a carrier of mammalian enzymes - proteases and organic acids. Thus, the acid complex of plantain leaves is represented by: fumaric, oxalic (31-103 $\mathrm{mg} \%)$ [4], tartaric $(1.60-1.87 \%)$, citric $(1.22-1.53 \%)$, malic $(0,20-0.51 \%)$, malonic $(0.11-$ $0.35 \%)$ and succinic $(0.25-0.55 \%)$ acids. The total content of organic acids is $10-12 \%$, of which up to $60 \%$ are related [5].

Due to the availability of sources and the relative ease of obtaining, such plant coagulants with different mechanism of action are the subject of growing scientific and practical interest of specialists in the production of milk-protein products enriched with polyphenolic compounds. It is necessary to provide technological modes and methods of treatment that will allow to preserve biologically active substances as much as possible.

The harmful effects on the body of "free radicals" can be reduced by the systematic use of some herbal preparations, with high antioxidant activity, or by adjusting diets towards the consumption of the corresponding products.

It is known from literature sources [6] that the highest antioxidant activity has a vegetable raw material with a high content of phenolic and polyphenolic compounds, as well as vitamins $\mathrm{A}, \mathrm{E}, \mathrm{K}$ and $\mathrm{C}$. In addition, such compounds - such as phenolic terpenoids, carnosol - have similar activity, chamazulene, coumarin, quercitin and others.

Flavonoids are physiologically active substances that are involved in many biochemical processes in the body. More than 200 natural flavonoid substances have been identified and more than 40 species have been identified [7].

In view of the above, more research is needed on the use in the technologies of milkprotein concentrates of plant raw materials, namely juice from the ground part of the plantain, as a coagulant. Unlike food ingredients synthesized by the industrial process, natural raw materials components can be a valuable source of various biologically active substances for the human body, including polyphenolic compounds necessary to maintain normal homeostasis, meet energy, plastic needs, and others.

The aim of this work was to determine the degree of polyphenolic compounds transition into protein-plant concentrates under precipitation of milk proteins by Plantago major $L$. juice.

\section{Materials and methods}

\section{Materials}

The raw material for protein concentrates was normalized milk with a solids mass fraction of $(12.3 \pm 0.62) \%$, fat $-(2.6 \pm 0.13) \%$, protein $-(2.8 \pm 0.14) \%$, with active acidity $(6.9 \pm 0.35)$ units of $\mathrm{pH}$, density $-1027 \mathrm{~kg} / \mathrm{m}^{3}$. 
As a coagulant, the juice of direct extraction from the ground part of Plantago major was used with the following parameters: quantity of solids $-(4.5 \pm 0.23) \%$, active acidity (5.85 \pm 0.18$)$ units of $\mathrm{pH}$.

From the leaves of Plantago major by various researchers were isolated 15 compounds from the class of flavonoids [8]. They are all derivatives of the flavon. The first compounds that have been isolated are Baikalin and Scootarein [9]. The presence of apigenin, luteolin, luteolin-7-glycoside and some other flavonoids was also found in the composition of large plantain leaves [8]. The leaves of a large plantain contain most of Routine (40.3\%) [10].

A modified method for complex deposition of protein substances of milk with the juice of plantain large has been developed. Plantago major juice was introduced into the heated to 96-98 ${ }^{\circ} \mathrm{C}$ milk, stirred slightly and kept until the formation of a clot. The maximum precipitation of milk protein substances was observed with the introduction of $8 \pm 1 \%$ coagulant and the duration of the process $-2 \mathrm{~min}$. Then the clot was pressed for $15 \mathrm{~min}$ to separate the whey, which was picked to determine the content of polyphenolic compounds [11].

\section{Methods}

In the obtained milk-protein concentrate, the polyphenol content was determined by the calculation method. Previously, their contents and composition were investigated in plantain juice and whey obtained by high-performance liquid chromatography (HPLC) using system Prominence LC-20 Shimadzu (Japan). 96\% ethanol in a 1:1 ratio was added to the liquid samples, then filtered using a Supelco Iso-Disc Filters PTFE 25-4 syringe filter (25 mm x $0.45 \mu \mathrm{m})[12,13]$. The initial ratio of eluent components is $1: 9$. The methanol content of the eluent during the experiment was varied according to the following scheme:

- first $13 \mathrm{~min}$ - increase from 10 to $40 \%$;

- from $13 \mathrm{~min}$ to $20 \mathrm{~min}$ - from 40 to $53 \%$;

- from $20 \mathrm{~min}$ to $26 \mathrm{~min}$ - from 53 to $55 \%$;

- from $26 \mathrm{~min}$ to $40 \mathrm{~min}$ - holding 55\%;

- from $40 \mathrm{~min}$ to $41 \mathrm{~min}$ - reduction to $10 \%$;

- from $41 \mathrm{~min}$ to $56 \mathrm{~min}$ - holding $10 \%$.

The speed of the eluent is $0.5 \mathrm{ml} / \mathrm{min}$. The column temperature is $40^{\circ} \mathrm{C}$. The volume of the entered sample $-5 \mu$ l.

Identification of the substances in the extract was performed by comparing the retention time and spectral characteristics of the test substances with similar characteristics of the standards according to the method [14] identification of polyphenols. Chromatography was performed at 225, 255, 286 and $350 \mathrm{~nm}[14,15,16]$. For accurate identification of the test substances to specific groups of polyphenols, the following regulatory documents were used: chlorogenic and caffeic acids (phenolic acids), catechin (catechins), flavonols myricetin, quercetin and rutin, flavanones naringenin, naringin, hesperinidin, and protestin cyanidine (anthocyanins) (Sigma-Aldrich, Germany). The identification characteristics of these standards were obtained under the above conditions of chromatography. The "peak area content of the standard " calibration dependences were linear with an accuracy of at least $\mathrm{r}^{2}=0.994$.

Substances whose similarity level according to any standard was below $70 \%$ were classified as a group of unidentified substances and their content was determined by the standards with the highest similarity level. 


\section{Results and discussion}

\section{Determination of biologically active substances in Plantago major juice and whey}

To determine the degree of transition of biologically active substances into protein-plant concentrates, the polyphenolic composition of the coagulant - the juice from the ground part of the plantain and the serum obtained during the deposition of milk proteins, was analyzed. The colloidal state destabilization of sol of casein micelles occurs under the action of proteolytic enzymes and changes in $\mathrm{pH}$ value. Milk gel is a structure consisting of a gel frame filled with whey. A characteristic feature of the gel is syneresis - a decrease in water-binding capacity under the influence of temperature, $\mathrm{pH}$ value and mechanical action [17]. In the classic embodiment, the concentrates contain only the casein fraction of milk proteins or manufactured with the addition of various chemicals of artificial origin (lactic, ascorbic, acetic and other acids) during precipitation. Traditional methods of concentration have several disadvantages - the lack of complex precipitation of proteins, the use of animal coagulants, high processing temperatures, providing a clot of foreign taste and odor, obtaining a bunch with a dense consistency, and more. For research, coagulation of milk proteins with proteases and organic acids of Plantago major was performed.

The absorption spectra characteristic of these compounds were measured for the qualitative determination of biologically active substances. Flavonoids are completely released from the test samples of the alcohol solution, and the absorption spectra of the solutions have bands corresponding to phenolic compounds $(225-350 \mathrm{~nm})$.

The content of the test substances in the alcohol extract $\left(\mathrm{C}_{\mathrm{ex}} \mathrm{mg} / \mathrm{l}\right)$ and in the juice of the plantain $\left(\mathrm{C} \mathrm{mg} / \mathrm{l}_{\text {juice }}\right)$, which were identified as flavonoids, are presented in Table 1 .

The content of substances in the whey sample obtained by deposition of milk proteins with Plantago major juice, which were identified as flavonoids, are presented in Table 2.

Identification was performed by the similarity of maintenance time (T maintenance) of the test substances and the similarity index (Is), indicating the similarity between the substance and the spectral characteristics standard to which the substance is more similar.

A greater number of flavanoids were identified at a wavelength $(\lambda)$ of $225 \mathrm{~nm}$, which was used to calibrate the dependency "the peak area - content" (S) for a particular standard.

The design of the species - Quercetin - refers to accurately identified substances. Design of the rutin-L (routine) form - a substance belongs to the same group of polyphenols as rutin, ie in this case it is flavonol, and is a glycoside (or an aglycone depending on the name of the standard, for example, rutin is a glycoside, quercetin is an aglycone, daidzin is a glycoside, daidzein is an aglycone).

In the course of the study, substances (not included in Table 1,2) were identified that were not identified due to the low index of similarity with the standards. Their content is set to the standard with the highest similarity.

Substances belonging to the polyphenols were determined by peaks on the chromatograms (Figure 1,2) of plantain juice and whey after precipitation of the proteins by the plant coagulant.

The results obtained are presented on the chromatograms on Figure 1, 2. 
Table 1

Flavonoid content in plantain juice

\begin{tabular}{|c|c|c|c|c|c|c|c|}
\hline Peak & T maintenance & $\begin{array}{c}\text { Match } \\
\text { index, } I_{L}\end{array}$ & Identification & $\begin{array}{c}\lambda, \\
\mathbf{n m}\end{array}$ & $\begin{array}{c}S \\
\text { (y.e.) }\end{array}$ & $\begin{array}{c}\text { Cextract, } \\
\mathrm{mg} / \mathrm{l}\end{array}$ & $\begin{array}{c}\mathrm{C}, \\
\mathrm{mg} / \mathrm{I}_{\text {juice }}\end{array}$ \\
\hline 20 & 10.052 & 0.787 & catechin-L & 225 & 569483 & 11.92 & 23.85 \\
\hline 21 & 10.645 & 0.673 & catechin-L & 225 & 221883 & 4.65 & 9.29 \\
\hline 22 & 11.021 & 0.658 & catechin-L & 225 & 12590 & 0.26 & 0.53 \\
\hline 23 & 11.494 & 0.719 & catechin-L & 225 & 78780 & 1.65 & 3.30 \\
\hline 25 & 12.240 & 0.891 & naringin- $\mathrm{L}$ & 286 & 25290 & 1.21 & 2.42 \\
\hline 26 & 12.502 & 0.650 & hesperidin-L & 286 & 10619 & 0.69 & 1.38 \\
\hline 27 & 12.769 & 0.844 & catechin-L & 225 & 464447 & 9.73 & 19.45 \\
\hline 30 & 14.036 & 0.843 & catechin-L & 225 & 24309 & 0.51 & 1.02 \\
\hline 31 & 14.258 & 0.747 & catechin-L & 225 & 344752 & 7.22 & 14.44 \\
\hline 32 & 14.524 & 0.685 & myricetin-L & 255 & 23669 & 0.73 & 1.47 \\
\hline 37 & 16.096 & 0.934 & catechin-L & 225 & 44374 & 0.93 & 1.86 \\
\hline 38 & 16.267 & 0.843 & catechin-L & 225 & 248952 & 5.21 & 10.43 \\
\hline 39 & 16.865 & 0.875 & catechin-L & 225 & 145150 & 3.04 & 6.08 \\
\hline 40 & 17.125 & 0.938 & Naringin & 286 & 31679 & 2.06 & 4.12 \\
\hline 44 & 18.461 & 0.807 & Hesperidin & 286 & 95157 & 4.55 & 9.10 \\
\hline 50 & 20.256 & 0.933 & rutin-L & 255 & 268823 & 15.25 & 30.50 \\
\hline 51 & 20.567 & 0.672 & apigenin-L & 350 & 2348 & 0.07 & 0.14 \\
\hline 55 & 21.876 & 0.823 & naringin-L & 286 & 27823 & 1.33 & 2.66 \\
\hline 56 & 22.201 & 0.713 & rutin-L & 286 & 2519 & 0.11 & 0.22 \\
\hline 57 & 22.534 & 0.624 & apigenin-L & 350 & 3904 & 0.12 & 0.23 \\
\hline 58 & 22.899 & 0.739 & Luteolin & 350 & 8030 & 0.15 & 0.29 \\
\hline 61 & 25.639 & 0.854 & quercetin-L & 255 & 34893 & 0.90 & 1.79 \\
\hline
\end{tabular}

Table 2

Content of flavanoids in whey obtained by the juice deposition of milk proteins Plantago major

\begin{tabular}{|c|c|c|c|c|c|c|c|}
\hline Peak & T maintenance & $\begin{array}{c}\text { Match } \\
\text { index, } \mathbf{I}_{\mathbf{L}}\end{array}$ & Identification & $\begin{array}{c}\boldsymbol{\lambda}, \\
\mathbf{n m}\end{array}$ & $\begin{array}{c}\mathbf{S} \\
\mathbf{( y . e . )}\end{array}$ & $\begin{array}{c}\mathbf{C}_{\text {extract, }} \\
\mathbf{m g} / \mathbf{l}\end{array}$ & $\begin{array}{c}\mathbf{C}, \\
\mathbf{m g} / \mathbf{I}_{\text {sample }}\end{array}$ \\
\hline 15 & 9.151 & 0.863 & Catechin & 225 & 162942 & 3.41 & 6.82 \\
\hline 17 & 10.000 & 0.881 & catechin-L & 225 & 84781 & 1.78 & 3.55 \\
\hline 19 & 11.480 & 0.759 & catechin-L & 225 & 20216 & 0.42 & 0.85 \\
\hline 21 & 12.874 & 0.872 & catechin-L & 225 & 28707 & 0.60 & 1.20 \\
\hline 23 & 14.310 & 0.898 & catechin-L & 225 & 485960 & 10.18 & 20.35 \\
\hline 24 & 14.711 & 0.613 & myricetin-L & 255 & 16290 & 0.50 & 1.01 \\
\hline 27 & 16.140 & 0.954 & catechin-L & 225 & 12055 & 0.25 & 0.50 \\
\hline 28 & 16.407 & 0.843 & catechin-L & 225 & 9944 & 0.21 & 0.42 \\
\hline 30 & 17.049 & 0.954 & Naringin & 286 & 1333 & 0.06 & 0.13 \\
\hline 33 & 18.436 & 0.836 & Hesperidin & 286 & 6972 & 0.45 & 0.91 \\
\hline 38 & 19.787 & 0.642 & rutin-L & 255 & 4058 & 0.23 & 0.46 \\
\hline 39 & 20.253 & 0.820 & luteolin-L & 350 & 25057 & 0.45 & 0.91 \\
\hline
\end{tabular}




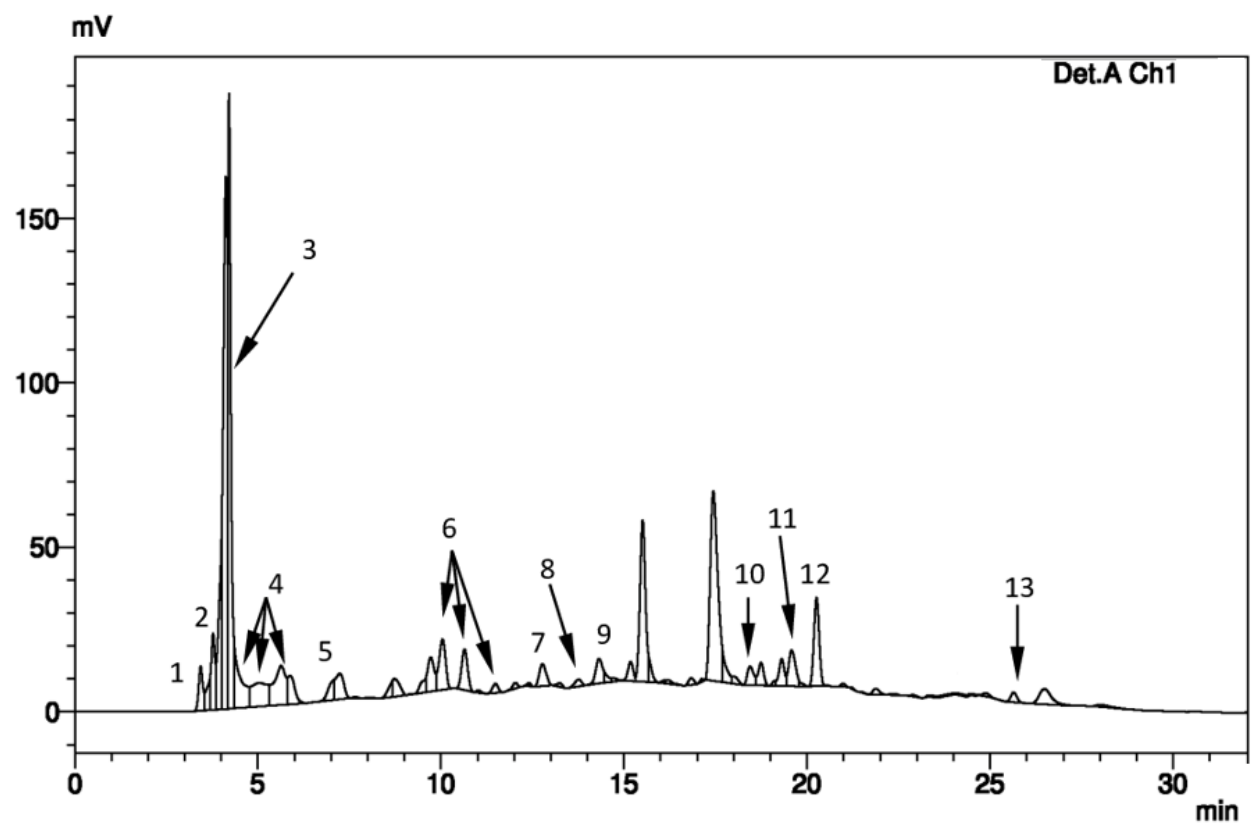

Figure 1. Chromatogram of plantain juice: catechin-like (1-5), catechins (6-7, 9), phenolic acids $(8,11)$, hesperidin (10), flavonol (glycoside) (12), flavonol (aglycone) (13).

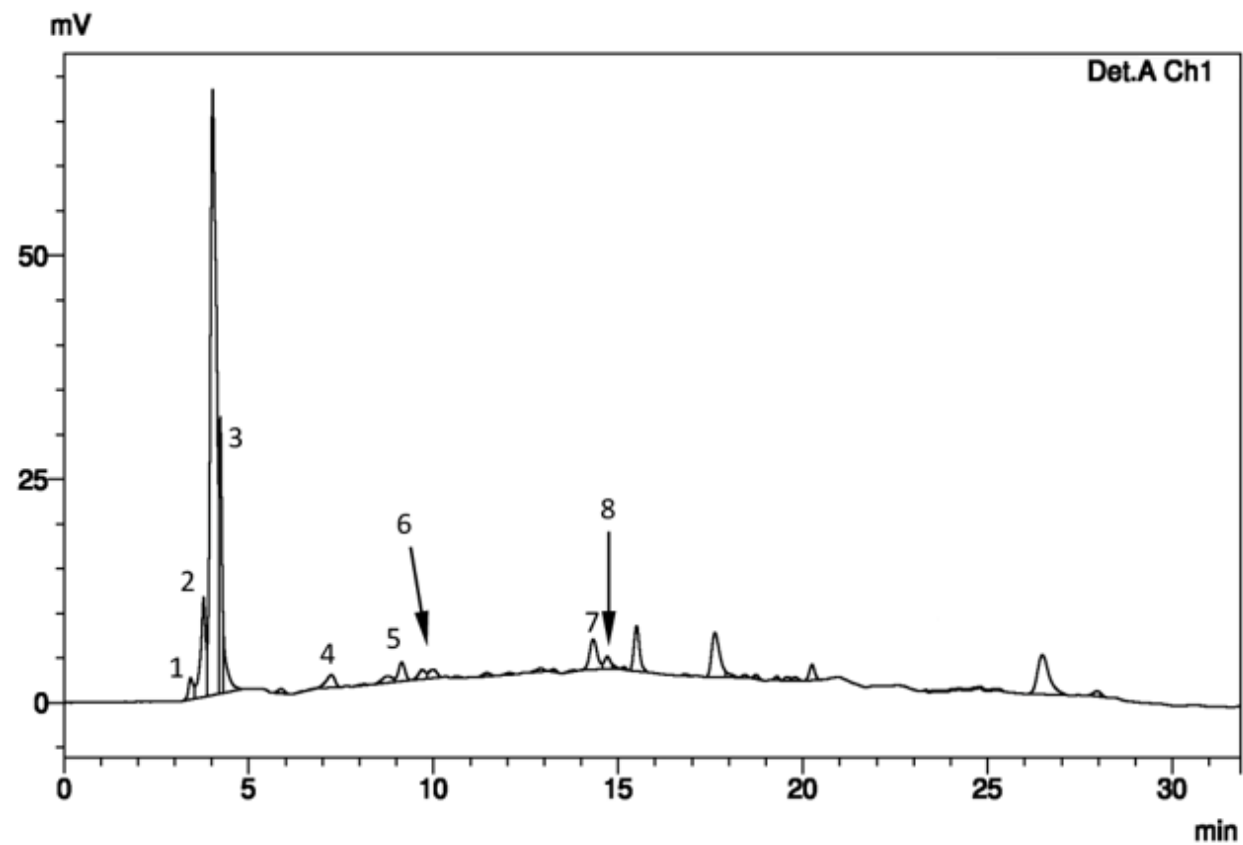

Figure 2. Chromatogram of whey after precipitation of milk proteins by plant coagulant: catechin-like (1-4), catechin (5), catechins $(6,7)$, myricetin glycosides $(8)$. 
Plantago major juice flavonoid composition is multicomponent. In the study of the type of absorption spectrum of alcohol extraction from the juice of the ground part of the plantain large found that the maximum is at a wavelength of $225-350 \mathrm{~nm}$. Of the 22 given flavonoids, 9 substances are 6-oxyflavones, characterized by a maximum within the range of 255-285 nm.

In total, 12 flavonoid-class compounds were identified in the colored whey that was removed after precipitation of milk proteins by plant coagulant, which is 10 fewer compared to their content in plantain juice. This is probably due to the fact that a considerable amount of the polyphenolic compounds from the juice have passed to the milk protein concentrate during denaturation.

\section{Determination of total content of polyphenols and flavonoids}

The total content of polyphenols in all samples was determined by summing the content of substances found in the range of peaks of flavonoids, neflavanoids and phenolic acids on the chromatograms. The polyphenols, whose peaks were located outside the area of the catechin peaks, but with the spectral characteristics of the catechins, were assigned to the catechin-like group and were not considered flavonoids. Their contents were 1036.72 and $166.53 \mathrm{mg} / \mathrm{l}$, respectively, in plantain juice and whey. The total content of flavonoids in all samples tested was equal to the content of substances that were similar to the standards of flavonoids (phenolic acids, catechins, flavonols, flavonones and flavones) with the exception of catechin-like substances. Flavonols are represented by the glycosides of myricin; naringin and hesperidin are part of flavonones; the flavones in the quantitative sense are the smallest and are represented by luteolin and its glycosides and glycosides of apigenin. Phenol acids content ranged from $12.36 \mathrm{mg} / \mathrm{l}$ for plantain juice and $0.07 \mathrm{mg} / \mathrm{l}$ for colored whey. The results of the study are presented in Table 3.

Table 3

Total composition and content of polyphenols in samples of plantain juice and whey

\begin{tabular}{|c|c|c|}
\hline \multirow{2}{*}{ A group of polyphenols } & \multicolumn{2}{|c|}{ Content, mg/l } \\
\hline & Plantain juice & Whey \\
\hline Phenolic acids & 12.36 & 0.07 \\
\hline $\begin{array}{r}\text { Catechins, including certain substances: } \\
\text { - catechin }\end{array}$ & 90.25 & $\begin{array}{c}33.69 \\
6.82\end{array}$ \\
\hline Catechin-like $*$ & 1036.72 & 166,53 \\
\hline $\begin{array}{c}\text { Flavonols, including certain substances: } \\
\text { - glycosides of myricin }\end{array}$ & $\begin{array}{c}33.98 \\
1.47\end{array}$ & $\begin{array}{l}1.47 \\
1.01\end{array}$ \\
\hline $\begin{array}{c}\text { Flavanones, including certain substances: } \\
\text { - naringin } \\
\text { - hesperidin }\end{array}$ & $\begin{array}{c}19.68 \\
4.12 \\
9.1\end{array}$ & $\begin{array}{l}1.04 \\
0.13 \\
0.91\end{array}$ \\
\hline $\begin{array}{l}\text { Flavones, including certain substances: } \\
\begin{aligned} & \text { - luteolin } \\
& \text { - glycosides of apigenin } \\
& \text { - glycosides of luteolin }\end{aligned} \\
\end{array}$ & $\begin{array}{l}0.52 \\
0.29 \\
0.23\end{array}$ & 0.31 \\
\hline Unidentified & 217.62 & 120.72 \\
\hline The sum of polyphenols & 1411.13 & 324.43 \\
\hline
\end{tabular}


The interaction of polyphenols with proteins depends on the structure of both polyphenol and protein, as well as the $\mathrm{pH}$ of the solution, ionic strength, temperature, polyphenol - protein ratio [18]. When binding, hydrophobic interplanar interactions of aromatic groups of amino acid residues of protein and polyphenols and (or) hydroxyl groups of polyphenols with a protein chain take place [19]. According to studies [20], the binding of polyphenols to different protein chains leads to the full or partial "unfolding" of the latter.

Therefore, the change of the native state of the protein is accompanied by the loss of the organized structure of the protein molecule without disruption of covalent bonds in them. In this case, the denaturation of both casein and serum proteins contributes to the increase of temperature and the process in the presence of the active complex Plantago major. During denaturation of proteins, hydrogen bonds and disulfide bridges that determine the spatial structure of their molecules are destroyed, which is accompanied by a change in the configuration, hydration, and aggregate state of the particles. The breaking of intramolecular bonds increases the reactivity of molecules, resulting in complexes between peptides and phenolic compounds.

The mechanism of polyphenols adsorption is to attach them to the protein globule surface at the time of deployment of the polypeptide chain due to the formation of a hydrogen bond between the hydroxyl group of the polyphenol and the carbonyl group of the protein molecule.

In the second stage, "Coagulational", destabilized protein molecule micelles by molecular interaction forces and calcium "bridges" are combined into aggregates, then into chains that are subsequently longitudinally and transversely structured into a spatial grid. In this case, the molecules of polyphenolic compounds are captured. There is a gelation process. At the final stage there is a structure formation and strengthening of a clot of proteinpolyphenoliphenol complexes. The quantitative reflection of this mechanism is presented in table. 3, where the difference between the values of the polyphenols content in juice and whey indicates the degree of their transition to protein-plant concentrate.

\section{Conclusions}

Thus, the amount of polyphenols in the plantain juice was $1411.13 \mathrm{mg} / \mathrm{l}$, and in the whey $-324.43 \mathrm{mg} / \mathrm{l}$, the content of flavonoids was fixed at $144.57 \mathrm{mg} / \mathrm{l}$ and $37.11 \mathrm{mg} / \mathrm{l}$, respectively. Having analyzed the results, we can conclude that the degree of transition of polyphenolic compounds into milk protein concentrate is $77 \%$ of the total number, including $74 \%$ of flavonoids.

Therefore, the binding of polyphenols by proteins depends on the structure of the protein molecule, the spatial distribution of amino acid residues responsible for the binding of polyphenols, and the number of conditions for such interaction. In addition, this relationship can cause a change in the spatial structure of the protein and affect the bioavailability of both components.

\section{References}

1. Slashcheva A. V., Nykyforov R. P., Popova S. Yu. (2016), Obgruntuvannia dotsilnosti vykorystannia bilkovo-vuhlevodnoho napivfabrykatu $\mathrm{v}$ tekhnolohii produktsii $\mathrm{z}$ 
dyspersnoiu strukturoiu, Vostochno-Evropeiskii zhurnal peredovykh tekhnolohii, 2/11(80), pp. 24-32.

2. Elena M., Emim J.,Souccar C., Lapa A. (1997), Analgesic and Anti-inflammatory Activities of the Aqueous Extract of Plantago major L., International Journal of Pharmacognosy, 35(2), pp. 99-104, DOI: 10.1076/phbi.35.2.99.13288

3. Najafian Y., Hamedi S., Farshchi M., Feyzabadi Z. (2018), Plantago major in Traditional Persian Medicine and modern phytotherapy: a narrative review. Electronic Physician, 10 (2), pp. 6390-6399, DOI: 10.19082/6390.

4. Guil, J.L., Torija, M.E., Gimenez, J.J., Rodríguez, I. (1996), Identification of Fatty Acids in Edible Wild Plants by Gas Chromatography. Journal of Chromatography, 719 (1), pp. 229-235, DOI: 10.1016/0021-9673(95)00414-9.

5. Olennikov, D.N., Tanhaieva, L.M., Mykhailova, T.M. Samuelsen, A.B. (2005), Organic acids of herbal plants 1. Plantago major L. Chemistry of Natural Connections, 41(4), 354-355, DOI: 10.1007/s10600-005-0180-1.

6. Holovko M.P., Penkina N.M., Kolesnyk V.V. (2011), Antioxidant properties of some kinds of vegetable raw material, Eastern-European Journal of Enterprise Technologies, 4,6(52), pp. 9-11.

7. Kamiyama V., Harakawa M., Otoguno C, Ozawa S. (2007), Iap. Soc. Food Sci. Technoi.,25, 1, pp. 36-40.

8. Olennikov D.N. (2007), Podorozhnik bolshoi. Khimicheskii sostav i primenenie, Khimiia rastitelnogo syria, 2, pp. 37-50.

9. Samuelsen A.B. (2000), The traditional uses, chemical constituents and biological activities of Plantago major. A review, Journal of Ethnopharmacology, 71, pp. 1-21.

10. Janković T., Zdunić G., Beara I., Balog K., Pljevljakušić D., Stešević D. Šavikin K. (2012), Comparative study of some polyphenols in Plantago species. Biochemical Systematics and Ecology, 42, pp. 69-74, DOI: 10.1016/j.bse.2012.02.013.

11. Grek O., Krasulya O., Chubenko L., Tymchuk A. (2018), The investigation of the potentional complex from plantago major to coagulate milk proteins, Food and Environment Safety, XVII(2), pp. 165-175.

12. Choma I., Olszowy M., Studziński M., Gnat S. (2019), Determination of chlorogenic acid, polyphenols and antioxidants in green coffee by thin-layer chromatography, effect-directed analysis and dot blot - comparison to HPLC and spectrophotometry methods, Journal of Separation Science, 42(8), pp. 1542-1549, DOI: $10.1002 /$ jssc. 201801174.

13. Malenčić D., Cvejić J., Miladinović J. (2012), Polyphenol Content and Antioxidant Properties of Colored Soybean Seeds from Central Europe, Journal of Medicinal Food, 15(1), pp. 89-95, DOI: 10.1089/jmf.2010.0329.

14. Khodakov I.V. (2013), Sposob identifikatsii polifenolov v rastitelnykh ekstraktakh pripomoshchi VEZhKh. Opredelenie sostava izoflavonov soi, Metody $i$ obieekty khimicheskogo analiza, 8(3), pp. 132-142.

15. Khodakov I.V. (2012), Sposob identifikatsii polifenolov v rastitelnykh ekstraktakh, Visnik stomatologii, 80(7), pp. 42.

16. Khodakov I.V., Makarenko O.A. (2010), Vysokoeffektivnaia zhidkostnaia khromatografiia vissledovanii rastitelnykh polifenolov, Visnik stomatologii, 73(5), pp. 59-60. 
17. Ostroumov L.A., Khusnullina N.V. (2010), Izuchenie kislotno-sychuzhnogo svertyvaniia moloka s primesiu SOM, Tekhnika i tekhnologiia pishchevykh proizvodstv, 1, pp. $1-5$.

18. Wang Sh, Liu Ff, Dong XY, Sun Y. (2010), Thermodynamic analysis of the molecular interactions between amyloid beta-peptide 42 and (-)- epigallocatechin-3-gallate, $J$ Phys Chem B.;114(35), pp. 11576-11583, DOI: 10.1021/jp1001435.

19. Bandyopadhyay P., Ghosh A.K, Ghosh C. (2012), Recent developments on polyphenolprotein interactions: effects on tea and coffee taste, antioxidant properties and the digestive system, Food Funct, 3(6), pp. 592-605, DOI: 10.1039/c2fo00006g.

20. Rawel H.M, Rohn S, Kroll J. (2003), Influence of a sugar moiety (rhamnosylglucoside) at 3-o position on the reactivity of quercetin with whey proteins, Int J Biol Macromol., 32(3-5), pp. 109-120, DOI: 10.1016/S0141-8130(03)00044-8. 